\title{
Higher Education and the Concurrence of the Students on the Future Labour Market
}

\author{
Erik Brezovec \\ Division of Sociology, University Department of Croatian Studies, University of \\ Zagreb, Croatia
}

\section{Abstract}

The paper analyzes the role of higher education in the ability of student adaptation (University of Zagreb) to new economic and market trends. Contemporary economic processes tend to develop competencies that encourage an individual for proactive action with the main characteristics of innovativeness and creativity. In other words, future employees or labour market participants are expected to be efficient in the implementation of acquired knowledge for the purpose of creating more efficient solutions for particular segments of the market. With this in mind, the main goal of the work is to explore, to what extent and in what ways does education correlate with the competitiveness of students in the labour market. How much is the knowledge acquired during the higher education process useful for students in defining their competitiveness on the Labour Market. Furthermore, students' views on their own competitiveness and market relevance are investigated. The applied research method is the method of survey on the student population at the University in Zagreb. According to research results that shows how the importance of competences varies in relation to the areas of science that students study, the possibilities of coexistence and complementarity between higher education principles and open market are examined.

Keywords: students, competencies, the labour market, competitiveness, education I JEL classification: I25

\section{Introduction}

Contemporary global economic situation creates a new reality of interaction on the labour market which highly depends on the individual competencies such as: proactivity, creativity, independency, team work (Martins et al., 2003). It also put on focus the knowledge and the information which became the dominant market factor (Castells et al., 2000). With that on mind, as Castells et al. (2000) clarify, we can talk about new age of Informational society. With the rise of Information society, labour market is changing its direction from the collective hierarchical corporation to more vertically oriented structure. That way, there is a need for the professional educated labour force, which do not depend on the others but to himself. On the labour market, employers are searching for the employee who will be ready for the new challenges that information society puts on them. They also need employee who is already built up professional with at least some experience.

New economic structure of labour market is presenting challenges for both Universities and students. Universities has to adapt to the Commodification of knowledge, and their use for the labour market. It is important to add that this new reality is confronting the basic humane, enlightened idea of higher education (Peračković, 2016). To put higher education on the influence of liberal market means reducing and destroying the idea of University as independent factor of creating a 
better world (Buroway, 2005). In that sense, science becomes the servant of the market needs. To confront this idea, there are the new theoretical ideas of the public sociology (Buroway, 2016). The main premises of this sociology is to confront the market with the public understanding of science as the general good that should not have price. The problem with commodification of knowledge however is the one of practical nature. Public sociology overs aw the problem of the acceptance that this situation holds by individual. Students go to college not only to provide the new knowledge's for themselves, but also to get the competencies that are needed for their future profession. If this profession is changed on the labour market, competencies need to be changed as well. It is utopia of thinking, that the knowledge can remain untouched by the global economy process. With that on mind we could put the classical sociology hierarchical triad with the economy on the top, culture 2nd, and politics 3rd. Economical processes are one of the main actors of structural and social changes in the reality of everyday life. According to that fact, traditional university concepts must evolve following the urging process of globalization and informational society (Krbec et al., 2001; p. 662).

Commodification of knowledge present a challenge for the students as well. The students have to understand the needs of the labour market. They have to adapt to the new social and structural reality and try their best to make their way on the labour market successfully. On the labour market they have to imply their knowledge to be competent and to find a job opportunity. To do so, students have to be aware of their abilities, their competencies and opportunities on the labour market. They have to know the basics of how labour market in Republic of Croatia works.

The main goal of this paper is to investigate students' views on their own competitiveness and market relevance. Furthermore, the paper analyzes the role of higher education in the ability of student adaptation (University of Zagreb) to new economic and market trends in Republic of Croatia. The applied research method is the method of survey. Survey is going to be analyzed through the program for the statistical analysis SPSS. The applied statistical methods for this paper were the ones of inferential statistic and correlation analysis. With the Spearman coefficient of correlation, we have investigated some of the main relations in the problematic of competencies of students and their competitiveness on the labour marked by their own view of things. Alongside of this analysis, we grouped the student population in two factors based on their attitudes toward labour market.

\section{Theoretical premises of the research}

The science and higher education system is intertwined with partial interests, lobbies, scientific field views, or views from the perspective of higher education institutions. This reality cannot be structured with only one legal solution with that on mind, the academic community continues, for ten years, to operate under a law that opens up a space to the dominance of classical teaching, autonomy is treated very specific, liberal views on the penetration of the private sector, system of promotions is made very passable, and scientific excellence is just a principle (Filipić, 2014).

The reference above is not directly connected to the explanation of the research goals, but it provides us with a larger view of problems that are present in higher education. In his book, Filipic (2014), presents the macroeconomic problems in the higher education in Republic of Croatia. He investigates the neoliberal market, contemporary economy and its connection with the Croatian higher education system. The problematic of that kind demands a larger interdisciplinary perspective which would explain the massive amount of variables that inflict the everyday life of Croatian higher education institutions. One of the main problems Filipić confronts is 
the productivity of the scientific community on Universities and the very nature of it, which can highly correlate with the problem of the future competencies that students are provided with. We can find that the basic actions of academic community is going through the process of the routine publishing which holds the purpose of its own, not the scientific nor developmental one.

The purpose of this paper is not to enter deeply in the structural analysis of academic world, but to perceive the attitudes of the students on the University of Zagreb about their competitive potential on the labour market. The main research question is as follow: Are students from University of Zagreb, by their own opinion, ready for the labour market (are they satisfied with their professional identity)?

To answer this question, we have to theoretically investigate, how the young person can find his or her own professional identity in the world of the flow (Bauman, 2011). Can we see the professional identities of students as stable categories, or are they yet to be built in that direction? The main premises of the world of flow, liquid modernity is the fact, that no one is in control of the contemporary context. In that world of flow you have to build your own identity by yourself, accepting full responsibility for failure. That situation leads us, in so called tyranny of choice (Salecl, 2012). Identities are shifting according to the context to which persons has to adapt. The contemporary economy and labour marked are not characterized by the stability of value (in the sense of identity). Individual on the labour market has to revise their own identity, build themselves according to the needs, new knowledges or even new paradigms (political, economic, and cultural). If the flexibility of identity can be learned during college or higher education, this challenges and threats for (professional) identity could be lessened. Can a student build himself/herself as a stable professional in the identity sense through the process of higher education?

The other focus for this part of research is the problematic of the labour market. Weber defines the market (and the labour market with it) as the ongoing process of the narrow rationalization form of modern world. He did not view the market neither as positive nor negative factor. In the matter of fact, he sees a market as the positive rationalization example. However, he is deeply concerned with the position of the modern individual in the context of market rationalization. By his view, market rationalization is degrading the basic concept of freedom and meaning (Weber, 1978 in Peračković, 2008; p. 978). Freedom and meaning are philosophical premises that are important for the formation of subjective identity. It also provides the possibility of individual internalization of the objective, structural forms of everyday life (Pavić, 2004).

These two theoretical definitions (of Bauman and Weber) seems to be in contradiction, but if we examine problematic closer, we can see that those two processes are in the epistemological relation. Proposed relation creates an uncertain situation of everyday life for the individual. Person is pushed by the bureaucratic rationality that is presented by the marketization of society. Marketization destabilizes the meaning of the collective structures of identity. Identity becomes individualized and the meaning is purely subjective from the one hand and from the other hand, individual thrives for more stable structural components of identity. In other words, individual must have their own meaning of the society and structure (economical, cultural, political), but he/she also wants to be part of something bigger than their own meaning. In that place there is a strength of creative, scientific institutions, which has the authority (by the rationalization process) to guide the individual on the objectification of their meaning in the collective sense - bringing back the collective significance. The main problem is proposed, can the students in the contemporary 
flow gain this significance that can make them ready for the labour marked which is highly liquid in the identity sense.

\section{Liquid professional identity}

Synthesis of these theories can have implication on the context of the students in the Republic of Croatia. The destabilized collective meaning is present for the every young person in Croatia. The meaning of identity, presented on the college, is forming as a solid picture of the future competencies and possibilities that awaits students after they graduate. The main problem in this paper is that this professional identity that is formed on the college has to be questioned for its own coherence with the context of the contemporary labour market in Croatia. Higher education proposes the stable and universal knowledge, while labour market holds the meaning of its own, independent nature (nature of profit?). In the other words, is the professional identity of student sufficient for the context of the labour market today? Can they form a meaning on the dynamic labour market with the socially constructed roles and professional identity? We also have to put in mind the process of professional identity formation during "student life" period. Formation of that identity is considered to be individual with the assistance of structural components (institution of higher education). That means that the internalization of these collective components of professional identity will vary according to the possibilities of accepting our future role in society. The main theoretical assumption is that students who internalize their future professional role will have more opportunities and feel more confident on the labour market. This hypothesis will also be tested in the next chapters of paper.

For the purpose of the research there is a need to separate a professional identity from the other forms of collective identities. In this paper, we examine the factors that are important for the student's future profession and their orientation on the labour market. All the other forms of identity, although they can have impact on the formation of professional identity (Sen, 2007), are not of the relevance for this paper. The future research can provide that correlation, but the aims of this paper are focused on the above presented goals supported with the sufficient theoretical Synthesis of both liquid modernity (Bauman, 2011) and marketization of society (Weber, 1978).

\section{Methodology}

The proposed research has been conducted in the period of May, 2018. Quantitative research methods have been used as a tool for explaining our goals. Applied research method was the method of survey. The instrument of research consists of 23 questions and 33 variables. Survey mainly consists of the questions formed in the Likert scale type (Matell et al., 1971), and of questions of multiple choice., There was a one question of the open type. This question had the assignment to provide answers about faculty/department on which students study. After the field research this question has been coded by the fields of Science and Technology (Narodne Novine (Official Gazette), 2009).

Applied research method has been conducted through the technic of internet survey. With awareness of challenges that internet survey propose (Couper et al., 2007), quotes has been created that structuralized the students according to their fields of science they study. Survey has been conducted to the social networks, on which students gather in groups to share data on their process of study. Groups are 
of closed nature. Before entering and sharing survey, researcher had to ask the moderators of the groups for permission. After permission survey has been distributed.

\section{Sample}

The population of the research includes the students of University in Zagreb. Quote sampling method has been used. The main quoting criteria has been the field of science, which has been controlled, with the distribution of the survey amongst the student groups on social networks of specific science field of study. In addition, the criteria of studying on University in Zagreb has been thoroughly controlled. The planned sample of the research has been 200. At the end of the field work there was an amount of 164 surveys gathered. The structure of the main quota has been as follow in Table 1. The socio-demographic structure of the sample showed the dominance of the female students (Table 2), with $76,2 \%$.

Table 1

Fields of Science of respodnents

\begin{tabular}{lllll}
\hline & & \multicolumn{2}{l}{ Fields of Science } & \\
& Frequency & Percent & Valid Percent & Cumulative Percent \\
\hline Social & 70 & 42,7 & 42,7 & 42,7 \\
Humanities & 40 & 24,4 & 24,4 & 67,1 \\
Natural & 8 & 4,9 & 4,9 & 72,0 \\
Technical & 25 & 15,2 & 15,2 & 87,2 \\
Biomedical & 15 & 9,1 & 9,1 & 96,3 \\
Biotechnical & 5 & 3,0 & 3,0 & 99,4 \\
Academies of & 1 &, 6 &, 6 & 100,0 \\
art & 164 & 100,0 & 100,0 & \\
\hline Total & & &
\end{tabular}

Source: Authors' work

Table 2

Sex of respondents

\begin{tabular}{lllll}
\hline & \multicolumn{2}{c}{ Sex } & \\
& Frequency & Percent & Valid Percent & Cumulative Percent \\
\hline Male & 39 & 23,8 & 23,8 & 23,8 \\
Female & 125 & 76,2 & 76,2 & 100,0 \\
\hline Total & 164 & 100,0 & 100,0 & \\
\hline
\end{tabular}

Source: Authors' work

\section{Methods of analysis}

The results of the research have been analyzed with the help of the program for the statistical analyses SPSS. Goals are examined through the inferential statistics from the one side and the Pearson coefficient of correlation from the other side. We have also made a factor reduction on the subject of the attitude toward employment possibilities of different science fields. The main hypothesis of the research is as follow:

1) The students of University in Zagreb are not consider themselves ready for the labour market.

2) There is a correlation between the field of research and the need for it on the labour market.

3) The students of University in Zagreb do not think that the University quotas are adequate for the labour market.

4) There is a correlation between attitudes of the students toward their professional identity, field of science and their readiness for the labour market. 


\section{Research results}

According to the proposed hypothesis, we have examined the results that can be explained with the proposed theoretical concept. The first problematic of the research has been analyzed descriptively. Table 3 shows the basic descriptive data of the readiness of the students for the labour market in general. On the scale from 1 to 5 , where 1 is described as "not ready at all", and 5 is described as "absolutely ready" we can see that the most of the students would describe themselves as neither ready, neither not ready $(40,9 \%)$. Important fact is that more students generally consider themselves ready $(26,2 \%)$, or absolutely ready $(7,9 \%)$, than not ready $(17,7 \%)$ or not ready at all $(7,3 \%)$. It is also important to conclude that there is no statistically significant association between the sex and the readiness of students for the labour market. Chi square test (table 4 and 5 ) has shown us no association $(X 2(2)>=7,711, p=0.103)$

Table 3

Readiness for the Labour Market

\begin{tabular}{lllll}
\hline \multicolumn{5}{c}{ How well do you consider yourself ready for the labour market } \\
& Frequency & Percent & Valid Percent & Cumulative Percent \\
\hline $\mathbf{1}$ - Not ready at all & 12 & 7,3 & 7,3 & 7,3 \\
$\mathbf{2}$ & 29 & 17,7 & 17,7 & 25,0 \\
$\mathbf{3}$ & 67 & 40,9 & 40,9 & 65,9 \\
$\mathbf{4}$ & 43 & 26,2 & 26,2 & 92,1 \\
$\mathbf{5}$ - Absolutely ready & 13 & 7,9 & 7,9 & 100,0 \\
\hline Total & 164 & 100,0 & 100,0 & \\
\hline
\end{tabular}

Source: Authors' work

Table 4

Readiness by Sex

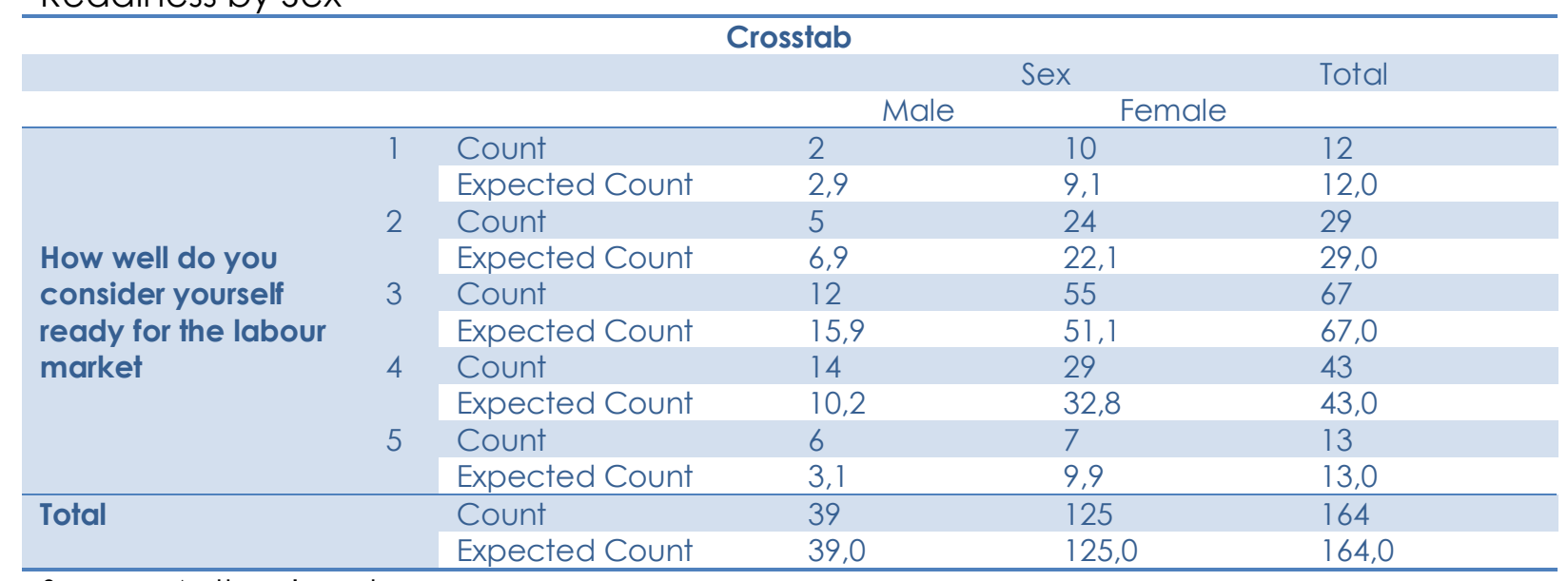

Source: Authors' work

Table 5

Chi-square Test of Readiness by Sex

\begin{tabular}{lccc}
\hline & Chi-Square Test & \\
& Value & Df & Asymp. Sig. (2-sided) \\
\hline Pearson Chi-Square & $7,711 a$ & 4 &, 103 \\
Likelihood Ratio & 7,249 & 4 &, 123 \\
Linear-by-Linear Association & 5,602 & 1 &, 018 \\
N of Valid Cases & 164 & & \\
\hline
\end{tabular}

Source: Authors' work 


\section{Correlations}

Pearson's coefficient of correlation has been used to examine the correlation strength between variables that are important for explaining hypothesis of research and goals of research. The first correlation table 6 shows us the correlation between readiness for the labour market and the interest for the field of study. The data shows us the week positive correlation between those two variables (.223).

Table 6

Correlation of Interest for the Field of Study and the Readiness for the Labour Market

\begin{tabular}{|c|c|c|c|}
\hline \multicolumn{4}{|c|}{ Correlations } \\
\hline & & $\begin{array}{l}\text { Interest for the } \\
\text { field of study }\end{array}$ & $\begin{array}{l}\text { Readiness for the Labour } \\
\text { market }\end{array}$ \\
\hline \multirow[t]{3}{*}{$\begin{array}{l}\text { Interest for the } \\
\text { field of study }\end{array}$} & $\begin{array}{l}\text { Pearson } \\
\text { Correlation }\end{array}$ & 1 & $0,223^{* *}$ \\
\hline & Sig. (2-tailed) & & 0,004 \\
\hline & $\mathrm{N}$ & 164 & 164 \\
\hline \multirow{3}{*}{$\begin{array}{l}\text { Readiness for } \\
\text { the labour } \\
\text { market }\end{array}$} & $\begin{array}{l}\text { Pearson } \\
\text { Correlation }\end{array}$ & $0,223^{* *}$ & 1 \\
\hline & Sig. (2-tailed) &, 004 & \\
\hline & $\mathrm{N}$ & 164 & 164 \\
\hline
\end{tabular}

Note: ${ }^{* *}$ - Correlation is significant at the 0.01 level (2-tailed)

Source: Authors' work

On the table 7 there is a visual correlation between the field of science that students study and their opinion about possibilities of finding a job after graduation with the social sciences. Using the Spearman's coefficient of correlation, data has shown us that there is mild negative correlation between these categories. Depending which field of science students study, they are going to have different opinions toward social sciences and the possibilities for it on the labour market.

Table 7

Correlation of Field of Science and the Attitude toward the Possibilities of Finding a Job of the People who get a Degree in the Social Field of Science

\begin{tabular}{|c|c|c|c|}
\hline \multicolumn{4}{|c|}{ Correlations } \\
\hline & & Field of science & $\begin{array}{l}\text { Possibilities for finding a job } \\
\text { after graduation: social field } \\
\text { of science }\end{array}$ \\
\hline \multirow[t]{3}{*}{ Field of science } & $\begin{array}{l}\text { Spearman } \\
\text { Correlation }\end{array}$ & 1 & $-0,404^{* *}$ \\
\hline & Sig. (2-tailed) & & 0,000 \\
\hline & $\mathrm{N}$ & 164 & 164 \\
\hline $\begin{array}{l}\text { Possibilities for } \\
\text { finding a job }\end{array}$ & $\begin{array}{l}\text { Spearman } \\
\text { Correlation }\end{array}$ &,$- 404^{* *}$ & 1 \\
\hline after graduation: & Sig. (2-tailed) & ,000 & \\
\hline $\begin{array}{l}\text { social field of } \\
\text { science }\end{array}$ & $N$ & 164 & 164 \\
\hline
\end{tabular}

Note: ** - Correlation is significant at the 0.01 level (2-tailed)

Source: Authors' work

\section{Descriptives}

To answer the goals of research and to make an adequate synthesis of theory and empirical data, an additional descriptive data has to be shown. In table 8 we can 
see the attitudes about the compatibility of the entry quotas on the Croatian Universities with the labour market. Data shows that $53,7 \%$ of the participants answered that quotas are not compatible, and $23,2 \%$ that quotas are not compatible at all. Cumulative percentage of those who think that quotas are compatible and fully compatible is $9,1 \%$. Most of the students think that quotas are not adequate for the current context of the labour market in Croatia.

Table 8

Compatibility of the Entry Quota on Universities in Croatia with the Labour Market Frequency Percent

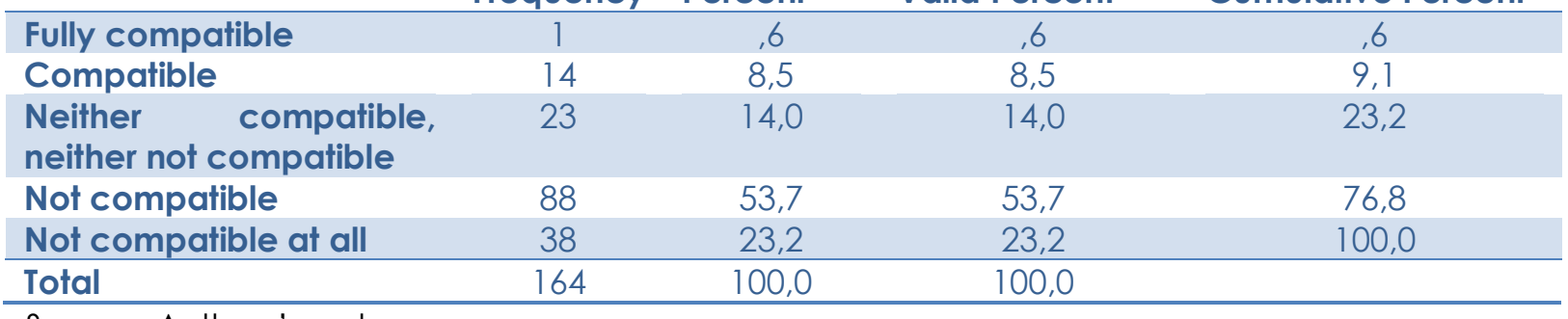

Source: Authors' work

However, competencies that students acquire during study are of importance for their professional identity. $47,6 \%$ of the participant students replied that they think competencies acquired during study are important for the future labour market (table 9). In addition, on the table 10 we have examined the importance of grades for the future labour market. For the $33 \%$ of the students, grades are not important for the labour market, and $16,5 \%$ thinks that grades are not important of all. Most of the students replied that grades are neither important, neither not important $(37,8 \%)$. All together it can be concluded that grades do not hold specific significance for the professional identity.

Table 9

Importance of the Competencies that Students Acquire During Study

\begin{tabular}{lcrcc} 
& Frequency & Percent & Valid Percent & Cumulative Percent \\
\hline Extremely important & 47 & 28,7 & 28,7 & 28,7 \\
Important & 78 & 47,6 & 47,6 & 76,2 \\
$\begin{array}{l}\text { Neither } \\
\text { neither not important }\end{array}$ & 25 & 15,2 & 15,2 & 91,5 \\
Not important & 12 & 7,3 & & \\
Not important at all & 2 & 1,2 & 1,3 & 100,8 \\
\hline Total & 164 & 100,0 & 100,0 & \\
\hline
\end{tabular}

Source: Authors' work

Table 10

Importance of the Grades on the Labour Market

\begin{tabular}{lcccc} 
& Frequency & Percent & Valid Percent & Cumulative Percent \\
\hline Extremely important & 1 &, 6 &, 6 &, 6 \\
Important & 19 & 11,6 & 11,6 & 12,2 \\
$\begin{array}{l}\text { Neither } \\
\text { neither not important }\end{array}$ & 62 & 37,8 & 37,8 & 50,0 \\
Not important & 55 & 33,5 & 33,5 & 83,5 \\
Not important at all & 27 & 16,5 & 16,5 & 100,0 \\
\hline Total & 164 & 100,0 & 100,0 & \\
\hline
\end{tabular}

Source: Authors' work 
The two more variables of the survey hold the importance for the theoretical side of the paper (table 11 and 12). It is compatibility of the competencies with the labour market and the importance of the chosen profession (of the students) for the development of Republic of Croatia. In table 11 it can be seen that students mostly find the competencies compatible with the labour market $(34,8 \%)$. It is also important fact that $31,1 \%$ of the sample thinks that competencies are neither compatible, neither not compatible. Competencies are one of the most important component of the professional identity. The indifference or ignorance of this component in this percentage $(31,1 \%)$ is proposing the questions of the internalization of objective components which has been discussed in the theoretical presumptions. The results also shows us that there is a more students in the sample that think that competencies are not compatible at all with the labour market $(7 \%)$, than there is a students which thinks that competencies are fully compatible (3\%)

Table 11

Compatibility of the Competencies on University with the Labour Market

\begin{tabular}{lcccc} 
& Frequency & Percent & Valid Percent & Cumulative Percent \\
\hline Fully compatible & 5 & 3,0 & 3,0 & 3,0 \\
Compatible & 57 & 34,8 & 34,8 & 37,8 \\
Neither compatible, & 51 & 31,1 & 31,1 & 68,9 \\
neither not compatible & & & & 23,8 \\
Not compatible & 39 & 23,8 & 7,3 & 92,7 \\
Not compatible at all & 12 & 7,3 & 100,0 & \\
\hline Total & 164 & 100,0 & & \\
\hline
\end{tabular}

Source: Authors' work

In the table 12 there is a visible significant importance that students have for their profession in the matter of the development of Republic of Croatia. It is important to mention that the development is considered purely as subjective. It depends on the perception of the development; social, political, economic, moral... In cumulative percentage, $64 \%$ of students hold their profession important for the development of Republic of Croatia.

Table 12

Importance of the Student Future Profession for the Development of Republic of Croatia

\begin{tabular}{|c|c|c|c|c|}
\hline \multicolumn{5}{|c|}{ How important is your profession for the development of Republic of Croatia? } \\
\hline & Frequency & Percent & Valid Percent & Cumulative Percent \\
\hline Extremely important & 29 & 17,7 & 17,7 & 17,7 \\
\hline Important & 76 & 46,3 & 46,3 & 64,0 \\
\hline $\begin{array}{l}\text { Neither important, } \\
\text { neither not important }\end{array}$ & 20 & 12,2 & 12,2 & 76,2 \\
\hline Not important & 29 & 17,7 & 17,7 & 93,9 \\
\hline Not important at all & 10 & 6,1 & 6,1 & 100,0 \\
\hline Total & 164 & 100,0 & 100,0 & \\
\hline
\end{tabular}

Source: Authors' work

\section{Discussion}

The results of the research indicate that the professional identity of the students at the University of Zagreb still highly depends on the process that is structurally built (by the top down approach). Students still rely on the higher education principles to provide them with the adequate competencies and security for the future labour 
market concurrence. The importance of the correlation between professional identity and labour market readiness is visible through the weak correlation that has been exposed in the table 6. The competencies students are provided at the higher education are considered important by the majority of the interviewed students (table 9). In the contemporary economic context, students consider their higher education important for their future. To question their professional identity entirely we examined the importance their profession hold for the development of the Croatian society. The importance during their student years indicate that they hold an importance of their future profession.

However, collective components of the professional identity have their negative sides which are not internalized by the students. The most important negative factor are the grades. The grades are not of the high importance for the students when they consider their future position on the labour market. That indicate the fact that professional identity of the students is not built by the grade system. Grade system (by the majority of sample) does not hold the important significance, but neither it is not important. That indifference shows the need of the restructuration of the grade system on the University so the labour market would recognize the grades as the factor of the good employee in the future.

\section{Conclusion}

The main goal of this paper was to investigate students' views on their own competitiveness and market relevance in the Republic of Croatia. This goal has been connected with the building up their own professional identity inside the structure of higher education. The research has shown that their own view of their competitiveness on the labour market and the relevance of their profession on the labour market is high and important for them. They consider themselves partially ready for the labour market and hold their profession important for the development of the Republic of Croatia. They consider the competencies that they are provided important for the future labour market, but the grades do not hold the important significance by the majority of sample students. Although students answered that the quotas are not adequate to the labour market, they still think that the competencies that they are provided are preparing them for the future labour market.

Altogether, it can be concluded that higher education system still provides the students with the components that they can use for building their own professional identity in the future, and with that, be concurrent on the labour market. There is a great important of those structural components, especially in the world of flow that neglect all the predominant factors of identity formations. With that form of trust, which higher education institutions have, comes the responsibility as toward the students as toward the labour market.

\section{References}

1. Bauman, Z. (2011), Tekuća modernost (Current modernity), Pelago, Zagreb.

2. Buroway, M. (2005), "For Public Sociology", American Sociological Review, Vol. 70, No. 1, pp. 4-28.

3. Buroway, M. (2016), "The Promise of Sociology: Global Challenges for National Disciplines", Sociology, Vol. 50, No. 5, pp. 949-959.

4. Castells, M., Andrić, O., Katunarić, V. (2000), Uspon umreženog društva (Networking), Golden marketing, Zagreb.

5. Couper, M. P., Kapteyn, A., Schonlau, M., Winter, J. (2007), "Noncoverage and nonresponse in an Internet survey", Social Science Research, Vol. 36, No. 1, pp. 131 148. 
6. Filipić, P. (2014), Anatomija destrukcije: politička ekonomija hrvatskog visokog školstva (Anatomy of Destruction: The Political Economy of Croatian Higher Education), Jesenski i Turk, Zagreb.

7. Krbec, D., Škare, M. (2003), "Implications of Changes in Higher Education on the Economy of Republic of Croatia", Društvena istraživanja, Vol. 12, No. 5, pp. 661-678.

8. Martins, E. C., Terblanche, F. (2003), "Building organisational culture that stimulates creativity and innovation", European journal of innovation management, Vol. 6, No. 1, pp. 64-74.

9. Matell, M. S., Jacoby, J. (1971), "Is there an optimal number of alternatives for Likert scale items? Study I: Reliability and validity", Educational and psychological measurement, Vol. 31, No. 3, pp. 657-674.

10. Narodne Novine (Official Gazette) (2009), Pravilnik o znanstvenim i umjetničkim područjima poljima i granama (Regulations about Scientific And Artistic Areas, Pole And Grants), NN 118/09, Nacionalno vijeće za znanost (National Council for Science), available at: https://narodne-novine.nn.hr/clanci/sluzbeni/2009_09_118_2929.html (05 June 2018)

11. Pavić, ž. (2004), Hegelova ideja logičke hermeneutike: samotumačenje apsoluta u vidljivoj nevidljivosti jezika (Hegel's Idea of Logical Hermeneutics: self-understanding of absolutes in visible invisibility of language), Breza, Zagreb.

12. Peračković, K. (2008), "Društvo i (ili) tržǐste - sociološka konceptializacija procesa marketizacije društva" (Society and (or) market-sociological conceptualization of the process of marketisation of society), Društvena istraživanja, Vol. 17, No. 6 (98), pp. 975 997.

13. Peračković, K. (2016), "Društvena uloga znanstvenika danas. Znanstvenik kao homo economicus i homo sociologicus versus homo academicus universalis" (The Social Role of Scientists Today. Scientist as Homo Economicus and Homo Sociologicus versus Homo Academicus Universalis), Filozofska istraživanja, Vol. 36, No. 3, pp. 581-593.

14. Salecl, R. (2012), Tiranija izbora (The tyranny of choice), Fraktura, Zagreb.

15. Sen, A. K. (2007), Identitet i nasilje: iluzija sudbine (Identity and violence: illusion of destiny), Masmedia, Zagreb.

16. Weber, M. (1978), Economy and Society I, University of California Press, Berkeley.

\section{About the author}

Erik Brezovec, Ph.D. candidate of Sociology at the Faculty of Humanities and Social Sciences, University in Zagreb and Croatology at the Department of Croatian Studies, University in Zagreb. He is a teaching assistant at the Department of Croatian studies at the University in Zagreb, division of sociology. Currently, he is a collaborator on the courses "Sociological theories 1", "Sociological theories 2" and "Contemporary sociological theories". His research interests are sociology of religion, sociology of addiction and the sociology of education. The author can be contacted at ebrezovec@hrstud.hr. 